\title{
HUBUNGAN GENETIK DAN PSIKOLOGIS DENGAN KEJADIAN DEPRESI PADA REMAJA
}

\author{
Genetic and Psychological Relationship with the Depression Event in Adolescents
}

\author{
Lidya Isnaini Nuriyah ${ }^{1}$, Ayik Mirayanti Mandagi ${ }^{2}$, Xindy Imey Pratiwi ${ }^{1}$ \\ ${ }^{1}$ Departemen Kesehatan Lingkungan, Fakultas Kesehatan Masyarakat, PSDKU Universitas Airlangga di Banyuwangi, \\ Banyuwangi, Indonesia \\ ${ }^{2}$ Departemen Epidemiologi, Biostatistika Kependudukan, dan Promosi Kesehatan, Fakultas Kesehatan Masyarakat, PSDKU \\ Universitas Airlangga di Banyuwangi, Banyuwangi, Indonesia \\ lidya.isnaini.nuriyah-2017@ fkm.unair.ac.id
}

\begin{abstract}
ARTICLE INFO

Article History: Received: August, $20^{\text {th }}$, 2021

Revised:

From

September, $27^{\text {th }}$, 2021

Accepted: October, $07^{\text {th }}$, 2021

Published online October, $11^{\text {th }}, 2021$

ABSTRACT

Depression is one of the most common types of mental disorders that can negatively affect a person's feelings, ways of thinking, and acting so that severe ones can lead to suicide. Depression's caused by various factors, which are genetic and psychological. This study was conducted to determine the relationship between genetic (gender and genetic history) and psychological (social support and psychosocial conditions) with the incidence of depression in adolescents (case study of XY High School students, Jember Regency). This research is an analytic observational study with a crosssectional method. The sample in this study was 158 respondents who were taken using the simple random sampling method. Data were collected online with the Social Provisions Scale (SPS), Youth Pediatric Symptom-17 (Y PSC-17), and Beck Depression Inventory-II (BDI-II) instruments. The research data were analyzed using the Spearman Correlation Test. The results showed that there was no relationship between genetics which consisted of gender variable $(p$ value $=0.958)$ and heredity history variable $(p$ value $=0.061$ ) with the incidence of depression in adolescents. While there is a relationship between psychology which consists of social support variables ( $p$ value $=$ 0.003 ) and psychosocial condition variables ( $p$ value $=0.000)$ with the incidence of depression in adolescents. The results of this study can be used as a basis for making preventive, promotive, and rehabilitative efforts regarding depression in adolescents and for further research.
\end{abstract}

Keywords: Depression, Genetic, Psychological, Adolescents.

\section{ABSTRAK}

Depresi adalah salah satu jenis gangguan mental paling umum terjadi, secara negatif mampu memengaruhi perasaan, cara berpikir dan bertindak seseorang sehingga pada tingkatan parah mampu menyebabkan bunuh diri. Depresi disebabkan oleh berbagai faktor, salah satunya adalah genetik dan psikologis. Penelitian ini dilakukan untuk mengetahui hubungan genetik (jenis kelamin dan riwayat keturunan) dan psikologis (dukungan sosial dan kondisi psikososial) dengan kejadian depresi pada remaja (studi kasus siswa SMA XY Kabupaten Jember). Penelitian ini merupakan penelitian observasional analitik dengan metode cross-sectional. Sampel dalam penelitian ini sebanyak 158 responden yang diambil menggunakan metode simple random sampling. Data diambil secara daring dengan instrumen Social Provisions Scale (SPS), Youth Pediatric Symptom-17 (Y PSC-17) dan Beck Depression Inventory-II (BDI-II). Data penelitian ini dianalisis menggunakan Uji Korelasi Spearman. Hasil penelitian menunjukkan bahwa tidak terdapat hubungan antara genetik yang terdiri dari variabel jenis kelamin $(\mathrm{p}$ value $=0.958)$ dan variabel riwayat keturunan $(\mathrm{p}$ value $=0.061)$ dengan kejadian depresi pada remaja. Sedangkan terdapat hubungan antara psikologis yang terdiri dari variabel dukungan sosial $(\mathrm{p}$ value $=0.003)$ dan variabel kondisi psikososial ( $\mathrm{p}$ value $=0.000$ ) dengan kejadian depresi pada remaja. Hasil penelitian ini dapat dijadikan dasar untuk pembuatan upaya preventif, promotif dan rehabilitatif perihal masalah depresi pada remaja serta menjadi landasan untuk penelitian lebih lanjut.

Kata Kunci: Depresi, Genetik, Psikologis, Remaja. 


\section{PENDAHULUAN}

Depresi adalah salah satu jenis gangguan mental yang paling umum terjadi di dunia (World Health Organization, 2015). Depresi menjadi penyakit yang secara negatif memengaruhi perasaan, cara berpikir dan tindakan seseorang dengan menimbulkan rasa sedih dan menghilangkan minat pada aktivitas seharihari atau aktivitas yang digemari (Meridien Research, 2021). Pada tingkat yang parah depresi diketahui dapat menyebabkan bunuh diri (World Health Organization, 2015). Diketahui telah terjadi sebanyak 800.000 kasus bunuh diri dilaporkan di seluruh dunia setiap tahunnya dengan depresi sebagai penyebab utama (World Health Organization, 2015). Sementara di Indonesia diketahui bahwa kejadian depresi telah dialami oleh sebanyak 35 juta orang (Kementerian Kesehatan Republik Indonesia, 2016).

Beberapa peneliti terdahulu menyatakan bahwa awal kemunculan depresi terjadi sejak periode kehidupan remaja (Thapar et al., 2012; Williams et al., 2014). Data pada tahun 2017 menunjukkan bahwa terdapat hampir 2,3 juta remaja pada rentang usia 12 hingga 17 tahun di Amerika Serikat mengalami paling sedikit satu kali kejadian depresi mayor (National Institute of Mental Health, 2017). Di Indonesia terdapat data yang menunjukkan bahwa ada lebih dari 3 juta remaja usia mulai dari 10 hingga 19 tahun yang mengalami gangguan mental dengan depresi paling umum terjadi (Badan Pusat Statistik, 2014).

Kejadian depresi pada remaja bukan hanya sekedar perasaan stres ataupun sedih, namun sudah menjadi keadaan serius yang dapat memengaruhi sifat, cara berpikir, dan berperilaku secara permanen sehingga membutuhkan penanganan yang serius (Azzahro et al., 2021).

Penyebab depresi berdasarkan hasil penelitian terdahulu diketahui dikarenakan oleh beberapa faktor seperti genetik, biologis, dan kondisi psikososial (Dianovinina, 2018). Selain itu masih terdapat banyak kemungkinan yang dapat menyebabkan depresi, seperti gangguan regulasi emosi, masalah kualitas hidup, harga diri yang rendah, pengalaman negatif hingga kurangnya dukungan keluarga (Marroquín \& Nolen-Hoeksema, 2015; Orth et al., 2016; Schirda et al., 2015; Vardanyan, 2013).

Para peneliti terdahulu menemukan bahwa genetik memengaruhi sebesar lebih dari $60 \%$ kejadian depresi berat pada seseorang (Purves et al., 2019). Sehingga ketika seseorang memiliki riwayat keturunan pernah mengalami depresi, ia memiliki kemungkinan lebih besar mengalami kejadian depresi. Selain itu jenis kelamin seseorang juga mempengaruhi kemungkinan ia dapat mengalami kejadian depresi. Beberapa peneliti terdahulu mengemukakan bahwa seseorang dengan jenis kelamin perempuan lebih mudah mengalami kejadi depresi (FernandezPujals et al., 2015; Hyland et al., 2020). Hal tersebut dikarenakan hormon pada perempuan lebih tidak stabil dibandingkan pada laki-laki, sehingga ketika terdapat faktor yang mampu memicu depresi maka seseorang dengan jenis kelamin perempuan dapat dengan mudah mengalami kejadian depresi (Fernandez-Pujals et al., 2015).

Pada faktor biologis diketahui terjadinya peningkatan kadar sitokin yang berkombinasi dengan penurunan kadar kortisol dapat menyebabkan kejadian depresi (Brogan, 2014). Hasil penelitian pada sudut pandang lainnya menunjukkan bahwa hampir 33\% kejadian depresi pada remaja disebabkan oleh kondisi psikososial (Azzahro et al., 2021). Kondisi psikososial yang diketahui dapat menyebabkan kejadian depresi pada remaja berkaitan dengan dukungan atau keterikatan emosional, integrasi sosial, kepastian nilai, bantuan nyata, pengenalan dan kesempatan pengasuhan yang baik (Azzahro et al., 2021).

Dampak terjadinya depresi pada remaja di Indonesia dapat dilihat dalam bentuk peningkatan konsumsi rokok, penyalahgunaan zat terlarang, kasus bunuh 
diri, dan penurunan fungsi sosial serta prestasi (Praptikaningtyas et al., 2019). Pernyataan tersebut diperkuat dengan data yang menunjukkan bahwa penyalahgunaan narkotika pada kalangan remaja di Indonesia dewasa ini meningkat sebesar hampir 30\% (Badan Narkotika Nasional Republik Indonesia, 2019). Berdasarkan pemaparan faktor penyebab dan dampak akibat kejadian depresi pada remaja, maka kejadian depresi perlu ditangani dengan cepat dan tepat agar tidak mengakibatkan permasalahan lebih lanjut bagi seseorang yang mengalaminya (Sulistyorini \& Sabarisman, 2017).

Penanganan dapat dilakukan sedari upaya pencegahan (preventive) hingga rehabilitatif. Peneliti terdahulu menunjukkan terdapat berbagai upaya yang dapat menurunkan kejadian depresi pada remaja seperti, pola asuh orang tua, efikasi diri, expressive writing therapy dan resiliensi individu (Danarti et al., 2018; Florensa et al., 2016; Safitri \& Hidayati, 2013; Shintia \& Maharani, 2021; Wahyuningsih \& Mamnu'ah, 2015). Pemilihan pola asuh orang tua yang demokratif diketahui secara signifikan berhubungan dengan rendahnya tingkat depresi pada remaja (Safitri \& Hidayati, 2013). Selain pemilihan pola asuh orang tua, peningkatan efikasi dan resiliensi diri juga berhubungan secara signifikan dengan penurunan depresi pada remaja (Florensa et al., 2016; Shintia \& Maharani, 2021). Selain itu terdapat alternatif lain yang terbukti berpengaruh terhadap penurunan depresi pada remaja, yaitu expressive writing therapy (Danarti et al., 2018).

Pemaparan data di atas menjadi dasar pelaksanaan penelitian ini. Penelitian ini dilakukan dengan tujuan mengidentifikasi hubungan genetik (jenis kelamin dan genetik atau riwayat keturunan) dan psikologis (dukungan sosial dan kondisi psikososial) dengan kejadian depresi pada remaja. Urgensi penelitian ini adalah sebagai bentuk kontribusi dalam memberikan informasi bagi para remaja, keluarga atau pihak terkait lainnya mengenai hubungan antara genetik dan psikologis dengan kejadian depresi. Penyampaian informasi tersebut diharapkan mampu mencegah masalah gangguan mental utamanya depresi secara lebih lanjut.

\section{METODE PENELITIAN}

Penelitian ini merupakan penelitian observasional analitik dengan metode cross-sectional. Penelitian ini dilakukan di beberapa Sekolah Menengah Atas (SMA) di Kabupaten Jember, Jawa Timur selama 3 bulan pada bulan April hingga Juni 2020. Populasi pada penelitian ini adalah seluruh siswa kelas 12 di lokasi penelitian dengan total sebanyak 350 orang responden.

Besar sampel dalam penelitian ini dihitung menggunakan Rumus Slovin dan menghasilkan jumlah sampel sebanyak 158 orang responden. Metode pengambilan sampel yang digunakan dalam penelitian ini adalah simple random sampling. Pengambilan sampel dilakukan dengan memasukkan daftar nama seluruh siswa kemudian akan dipilih secara acak pada laman daring wheel of names yang digunakan karena kemudahan dan otomatisasi penyimpanan nama terpilih. Sehingga meminimalisir adanya nama terpilih yang terlewatkan. Nama responden yang terpilih kemudian akan dihubungi oleh peneliti dan apabila bersedia akan diberikan link pengisian kuesioner.

Variabel bebas dalam penelitian ini antara lain genetik (jenis kelamin dan riwayat keturunan) dan psikologis (dukuangan sosial dan kondisi psikososial), sedangkan variabel terikatnya adalah kejadian depresi. Metode pengumpulan data pada penelitian ini adalah survei daring dengan melakukan pengisian kuesioner pada Formulir Google. Instrumen yang digunakan untuk meneliti genetik adalah pengisian data diri pada laman kuesioner. Instrumen yang digunakan untuk meneliti dukungan sosial menggunakan instrumen terstandar yaitu Social Provisions Scale (SPS) (Chiu et al., 2016). 
Instrumen yang digunakan untuk mengukur faktor psikososial adalah instrumen terstandar yaitu Youth Pediatric Symptom-17 (Y-PSC-17) (Murphy et al., 2016). Y-PSC-17 dapat digunakan untuk mengukur faktor psikososial pada anak usia sekolah hingga usia remaja akhir yaitu pada usia 4 hingga 24 tahun. Sementara itu instrumen yang digunakan untuk meneliti kejadian depresi pada remaja adalah kuesioner Beck Depression Inventory-II (BDI-II) (Uin \& Hidayatullah, 2018).

Pengolahan dan analisis data dilakukan menggunakan aplikasi SPSS 21 dengan analisis univariat dan analisis statistik non parametrik. Analisis univariat dalam penelitian ini dilakukan untuk mengetahui distribusi frekuensi data penelitian, sedangkan analisis statistik non parametrik dilakukan untuk menguji hubungan antar variabel. Analisis statistik non parametrik yang digunakan dalam penelitian ini adalah Uji Korelasi Spearman.

\section{HASIL}

\section{Distribusi Frekuensi Variabel}

Data pada tabel 1 menunjukkan bahwa mayoritas responden berjenis kelamin perempuan sebesar $76,6 \%$ dan sisanya sebesar $23,4 \%$ adalah laki-laki. Diketahui pula bahwa mayoritas responden tidak memiliki riwayat keturunan pernah mengalami depresi (93,0\%). Sebagian besar reponden juga memiliki tingkat dukungan sosial yang baik $(57,0 \%)$. Meskipun gambaran kondisi psikososial pada responden seimbang yaitu pada kondisi baik maupun terganggu. Namun diketahui bahwa mayoritas responden tidak mengalami kejadian depresi $(54,4 \%)$.

Berdasarkan interpretasi tersebut dari penelitian yang telah dilakukan maka dapat diketahui distribusi frekuensi data responden melalui tabel berikut:
Tabel 1. Distribusi Frekuensi Variabel Data Responden Tahun 2020.

\begin{tabular}{|c|c|c|}
\hline Variabel & n & $\%$ \\
\hline \multicolumn{3}{|l|}{ Jenis Kelamin } \\
\hline Laki-Laki & 37 & 23,4 \\
\hline Perempuan & 121 & 76,6 \\
\hline \multicolumn{3}{|l|}{ Riwayat Keturunan } \\
\hline $\begin{array}{ll}\text { Memiliki } & \text { riwayat } \\
\text { keturunan } & \end{array}$ & 11 & 7,0 \\
\hline $\begin{array}{l}\text { Tidak memiliki riwayat } \\
\text { Keturunan }\end{array}$ & 147 & 93,0 \\
\hline \multicolumn{3}{|l|}{ Dukungan Sosial } \\
\hline Baik & 90 & 57,0 \\
\hline Buruk & 68 & 43,0 \\
\hline \multicolumn{3}{|l|}{ Kondisi Psikososial } \\
\hline Baik & 79 & 50,0 \\
\hline Terganggu & 79 & 50,0 \\
\hline \multicolumn{3}{|l|}{ Kejadian Depresi } \\
\hline Depresi & 72 & 45,6 \\
\hline Tidak Depresi & 86 & 54,4 \\
\hline
\end{tabular}

Sumber: Data primer, 2020

\section{Hubungan Antar Variabel}

Analisis hubungan antar variabel dilakukan menggunakan Uji Korelasi Spearman dengan signifikansi 0,05. Hasil uji korelasi Spearman ini diambil dengan dasar pengambilan keputusan melihat nilai korelasi koefisien dan signifikansi antar variabel. Selain itu analisis ini dilakukan untuk melihat hubungan antar variabel secara parsial. Hasil uji analisis dicantumkan dalam tabel 2.

Data tabulasi silang pada tabel 2 menunjukkan bahwa mayoritas responden perempuan yang mengalami kejadian depresi sejumlah 55 orang $(34,8 \%)$. Sedangkan responden laki-laki yang mengalami kejadian depresi sejumlah 17 orang $(10,8 \%)$. Pada sudut pandang riwayat keturunan diketahui mayoritas remaja yang mengalami kejadian depresi tidak memiliki riwayat keturunan orang tua pernah mengalami gangguan depresi sejumlah 64 orang $(40,5 \%)$. Sedangkan remaja dengan riwayat keturunan yang mengalami kejadian depresi sejumlah 8 orang $(5,0 \%)$. 
Tabel 2. Hubungan antara Genetik dan Psikologis dengan Kejadian Depresi pada Remaja Tahun 2020

\begin{tabular}{|c|c|c|c|c|c|c|c|c|c|}
\hline & \multicolumn{4}{|c|}{ Kejadian Depresi } & \multirow{2}{*}{\multicolumn{2}{|c|}{ Total }} & \multirow{3}{*}{$\begin{array}{l}\text { Koefisien } \\
\text { Korelasi }\end{array}$} & \multirow[t]{3}{*}{ Sig. } \\
\hline & & \multicolumn{2}{|c|}{ Depresi } & \multicolumn{2}{|c|}{$\begin{array}{c}\text { Tidak } \\
\text { Depresi }\end{array}$} & & & & \\
\hline & & $\mathbf{n}$ & $\%$ & $\mathbf{n}$ & $\%$ & $\mathbf{n}$ & $\%$ & & \\
\hline \multicolumn{10}{|l|}{ Genetik } \\
\hline \multirow{2}{*}{$\begin{array}{l}\text { Jenis } \\
\text { Kelamin }\end{array}$} & Laki-Laki & 17 & 10,8 & 20 & 12,8 & 37 & 23,4 & \multirow[t]{2}{*}{$-0,004$} & \multirow[t]{2}{*}{0,958} \\
\hline & Perempuan & 55 & 34,8 & 66 & 41,8 & 121 & 76,6 & & \\
\hline \multirow{2}{*}{$\begin{array}{l}\text { Riwayat } \\
\text { Keturunan }\end{array}$} & Ada & 8 & 5,0 & 3 & 2,0 & 11 & 7,0 & \multirow[t]{2}{*}{0,149} & \multirow[t]{2}{*}{0,061} \\
\hline & Tidak ada & 64 & 40,5 & 83 & 52,5 & 147 & 93,0 & & \\
\hline \multicolumn{10}{|l|}{ Psikologis } \\
\hline \multirow{2}{*}{$\begin{array}{l}\text { Dukungan } \\
\text { Sosial }\end{array}$} & Baik & 32 & 20,3 & 58 & 36,7 & 90 & 57,0 & \multirow[t]{2}{*}{$-0,231^{* *}$} & \multirow[t]{2}{*}{0,003} \\
\hline & Buruk & 40 & 25,3 & 28 & 17,7 & 68 & 43,0 & & \\
\hline \multirow{2}{*}{$\begin{array}{l}\text { Kondisi } \\
\text { Psikososial }\end{array}$} & Baik & 20 & 12,7 & 59 & 37,3 & 79 & 50,0 & \multirow[t]{2}{*}{$-0,407^{* *}$} & \multirow[t]{2}{*}{0,000} \\
\hline & Terganggu & 52 & 32,9 & 27 & 17,1 & 79 & 50,0 & & \\
\hline
\end{tabular}

${ }^{* * *}$ Berhubungan secara signifikan pada $\alpha=0.01$

Sumber: Data primer, 2020

Pada sudut pandang faktor psikologis diketahui bahwa mayoritas responden dengan dukungan sosial yang baik tidak mengalami kejadian depresi yaitu sebanyak 58 orang dari total 90 responden atau sebesar $36,7 \%$. Sedangkan responden dengan dukungan sosial yang buruk mayoritas mengalami kejadian depresi dengan jumlah 40 orang dari total 68 responden atau sebesar $25,3 \%$. Hal serupa juga terjadi pada data variabel psikososial yang menunjukkan sebanyak 59 orang dari total 79 responden dengan kondisi psikososial baik tidak mengalami kejadian depresi atau sebesar 37,3\%. Sementara sebanyak 52 orang dari total 79 responden dengan kondisi psikososial terganggu mengalami kejadian depresi atau sebesar $32,9 \%$.

Hasil uji korelasi spearman pada tabel 2 menunjukkan bahwa variabel jenis kelamin (sig. 0,958) dan riwayat keturunan (sig. 0,061) tidak berhubungan secara signifikan dengan kejadian depresi pada remaja karena memiliki nilai signifikansi > 0,05 . Sedangkan variabel dukungan sosial (sig. 0,003) dan psikososial (sig. 0,000) berhubungan secara signifikan dengan kejadian depresi pada remaja karena memiliki nilai signifikansi $<0,05$. Sehingga diketahui bahwa genetik tidak memiliki hubungan dengan kejadian depresi pada remaja, sedangkan psikologis memiliki hubungan dengan kejadian depresi pada remaja.

Pada tabel 2 juga ditunjukkan kuat dan nilai hubungan antar variabel. Variabel dukungan sosial diketahui berhubungan sangat lemah bernilai negatif (tidak searah) dengan kejadian depresi pada remaja. Berbeda dengan variabel dukungan sosial, varibel psikososial memiliki hubungan yang cukup kuat dengan kejadian depresi pada remaja meskipun sama-sama bernilai negatif (tidak searah). Hal tersebut bermakna bahwasannya apabila seorang remaja mendapatkan dukungan sosial dan psikososial yang semakin baik maka remaja tersebut semakin minim mengalami kejadian depresi.

\section{PEMBAHASAN}

Hasil penelitian ini menunjukkan bahwa kejadian depresi yang dilihat dari sudut pandang jenis kelamin tidak berhubungan secara signifikan. Hal tersebut terlihat pada data bahwasannya baik remaja dengan jenis kelamin laki-laki maupun perempuan memilki probabilitas yang sama 
dalam mengalami kejadian depresi. Hasil ini menunjukkan bahwa jenis kelamin tidak menentukan seseorang akan lebih mungkin mengalami kejadian depresi. Pada variabel riwayat keturunan menunjukkan bahwa remaja yang memiliki riwayat keturunan depresi lebih berpotensi mengalami kejadian depresi. Namun ketika dilakukan uji analisis hubungan menunjukkan hasil bahwa riwayat keturunan tidak berhubungan secara signifikan dengan kejadian depresi. Sehingga meskipun seorang remaja tersebut berpotensi belum tentu akan benar-benar mengalami kejadian depresi.

Hasil uji hubungan antara genetik dengan kejadian depresi pada penelitin ini sejalan dengan penelitian terkini yang juga menyatakan bahwa riwayat keturunan tidak berhubungan dengan kejadian depresi yang dialami oleh para remaja utamanya siswa SMA (Herfinanda \& Kaloeti, 2021). Hasil uji hubungan antara psikososial dengan kejadian depresi pada penelitian ini sejalan dengan hasil penelitian lainnya yang menyatakan bahwa dukungan sosial dan kondisi psikososial berhubungan dengan kejadian depresi pada remaja (Azzahro et al., 2021; Bintang \& Mandagi, 2021; Rahmayanti \& Rahmawati, 2018; Syahputra et al., 2018).

Dukungan sosial diketahui berhubungan dengan kejadian depresi secara signifikan bernilai negatif (tidak sejalan). Sehingga ketika terjadi peningkatan dukungan sosial maka terjadi penurunan kemungkinan kejadian depresi pada remaja (Bintang \& Mandagi, 2021; Rahmayanti \& Rahmawati, 2018; Syahputra et al., 2018).

Kondisi psikososial diketahui memiliki hubungan yang signifikan bernilai negatif (tidak sejalan) dengan kejadian depresi pada remaja. Sehingga ketika kondisi psikososial seseorang semakin membaik maka akan terjadi penurunan kemungkinan kejadian depresi pada remaja (Azzahro et al., 2021). Hasil tersebut sejalan dengan beberapa penelitian sebelumnya yang juga menyatakan bahwa kejadian depresi berhubungan dengan kondisi psikososial yang dialami seseorang (Azzahro et al., 2021; Haryanto et al., 2015; Marsasina \& Fitrikasari, 2016; Putri \& Tobing, 2020; Santoso et al., 2018).

Dukungan sosial dan kondisi psikososial diketahui sebagai variabel yang berjalan seiringan, dimana pemberian dukungan sosial yang positif pada seseorang dapat meningkatkan kondisi psikososialnya ke arah lebih baik dan mencegah terjadinya gangguan atau permasalahan psikososial (Fitria \& Maulidia, 2018). Hal tersebut diperkuat dengan hasil penelitian lainnya yang menyatakan bahwa sebesar hampir $80 \%$ remaja membutuhkan dukungan sosial dari keluarga dalam bentuk dukungan emosional untuk lebih mempersiapkan diri dalam menghapi permasalahan yang sedang dihadapi (Fitria \& Maulidia, 2018).

Penelitian ini tentunya belum sepenuhnya sempurna, masih perlu dilakukan penelitian lebih lanjut terkait topik serupa bahkan dengan variabel yang lebih luas. Hal tersebut dikarenakan penelitian ini masih memiliki keterbatasan dalam proses pengambilan data. Pengambilan data yang dilakukan secara daring dari responden membuat peneliti tidak dapat mendampingi selama proses pengisian data. Sehingga mengakibatkan beberapa responden mengalami kesulitan memahami pertanyaan dalam kuesioner.

Mempertimbangkan kondisi pandemi COVID-19 saat dilakukannya penelitian ini juga dapat diketahui bahwa terdapat banyak faktor eksternal individu yang secara ekstrem lebih mempengaruhi kejadian depresi pada remaja (Adhikari et al., 2020; Brooks et al., 2020; Cornine, 2020; De Olivera F et al., 2020; Duan \& Zhu, 2020; Hasanah et al., 2020; Huang et al., 2020; Hyland et al., 2020; Liang et al., 2020; Maia \& Dias, 2020; Mazza et al., 2020; Sahu, 2020). Faktor eksternal tersebut meliputi, krisis global, pandemi dunia, tekanan psikologis, tekanan ekonomi, kekurangan sumber daya, kerugian sosial, kerugian finansial, pemberlakukan jaga jarak dan 
karantina mandiri (Adhikari et al., 2020; Brooks et al., 2020; Cornine, 2020; De Olivera F et al., 2020; Huang et al., 2020; Hyland et al., 2020; Liang et al., 2020; Mazza et al., 2020; Sahu, 2020). Sehingga keterbatasan variabel pengujian ini tidak dapat mengimbangi faktor eksternal lain yang juga mempengaruhi kejadian depresi pada responden penelitian. Penelitian ini juga hanya dilakukan pada satu kabupaten sehingga belum bisa menginterpretasikan kondisi di seluruh Indonesia.

Maka dari itu dapat dilakukan penelitian serupa di berbagai lokasi lainnya di Indonesia maupun negara lainnya dengan responden yang memiliki kriteria sama. Meskipun demikian penelitian ini layak digunakan sebagai literatur atau pertimbangan pada penelitian selanjutnya melihat kuatnya teori atau penelitian sebelumnya yang melengkapi hasil penelitian ini.

\section{SIMPULAN DAN SARAN}

Kesimpulan dari sosialisasi ini adalah bahwa presentasi dan video animasi singkat dapat meningkatkan pengetahuan dan pemahaman remaja mengenai kecanduan gawai. Sebagai saran, program promosi mengenai penggunaan gawai yang sehat pada remaja dapat mencontoh metode ini. Studi berikutnya perlu melaporkan status kecanduan gawai dan hasil intervensi yang dilakukan untuk mencegah kecanduan gawai pada kelompok umur ini.

\section{UCAPAN TERIMA KASIH}

Terima kasih kepada seluruh tim peneliti dan tim pengumpul data atas kontribusinya dalam penelitian ini dari awal hingga akhir. Sejak rumusan masalah, penyusunan proposal, instrumen penelitian dan perizinan hingga pelaporan hasil penelitian. Terima kasih juga kepada para responden yang bersedia mengikuti penelitian ini. Terima kasih juga kepada Universitas Airlangga yang telah membantu dan mendukung penelitian ini.

\section{REFERENSI}

Adhikari, S. P., Meng, S., Wu, Y. J., Mao, Y. P., Ye, R. X., Wang, Q. Z., Sun, C., Sylvia, S., Rozelle, S., Raat, H., \& Zhou, H. (2020). Epidemiology, Causes, Clinical Manifestation And Diagnosis, Prevention And Control Of Coronavirus Disease (COVID19) During The Early Outbreak Period: A Scoping Review. Infectious Diseases of Poverty, 9(1), $1-12$.

Azzahro, E. A., Dian, J., Sari, E., Masyarakat, F. K., Epidemologi, D., Kesehatan, F., \& February, F. (2021). Faktor Psikososial Dengan Kejadian Depresi Pada Remaja (Studi pada Siswa Kelas 12 SMA XY Jember) Psychosocial Factors with The Incidence of Depression in Adolescents (Study at 12th Grade $\mathrm{XY}$ High Schools Students in Jember). 2655, 69-77.

Badan Narkotika Nasional Republik Indonesia. (2019). Penggunaan Narkotika di Kalangan Remaja Meningkat. https://bnn.go.id/.

Badan Pusat Statistik. (2014). Data Remaja Teridentifikasi Depresi. www.bps.go.id.

Bintang, A. Z., \& Mandagi, A. M. (2021). Kejadian Depresi Pada Remaja Menurut Dukungan Sosial Di Kabupaten Jember. Journal of Community Mental Health and Public Policy, 3(2), 92-101.

Brogan, K. (2014). How Inflammation and Depression Gave Birth to New Medicine. https://kellybroganmd.com/.

Brooks, S. K., Webster, R. K., Smith, L. E., Woodland, L., Wessely, S., Greenberg, N., \& Rubin, G. J. (2020). The Psychological Impact Of Quarantine And How To Reduce 
It: Rapid Review Of The Evidence. The Lancet, 395(10227), 912-920.

Chiu, C.-Y., Motl, R. W., \& Ditchman, N. (2016). Validation of the Social Provisions Scale in people with multiple sclerosis. Rehabilitation Psychology, 61(3), 297-307.

Cornine, A. (2020). Reducing Nursing Student Anxiety in the Clinical Setting: An Integrative Review. Nursing Education Perspectives, 41(4), 229-234.

Danarti, N. K., Sugiarto, A., \& Sunarko. (2018). Pengaruh Expressive Writing Therapy Terhadap Penurunan Depresi, Cemas, dan Stres. Journal Ilmu Keperawatan Jiwa, 1(1), 48-61.

De Olivera F, Abrantes L, Martins P, Bezerra C, \& Rolim M. (2020). Impact Of Sars-Cov-2 And Its Reverberation In Global Higher Education And Mental Health. Psychiatry Research journal; 288: 12. January.

Dianovinina, K. (2018). Depresi pada Remaja: Gejala dan Permasalahannya. Journal Psikogenesis, 6(1), 69-78.

Duan, L., \& Zhu, G. (2020). Psychological Interventions for People Affected by the COVID-19 Epidemic. The Lancet Psychiatry, 7(4), 300-302. h

Fernandez-Pujals, A. M., Adams, M. J., Thomson, P., McKechanie, A. G., Blackwood, D. H. R., Smith, B. H., Dominiczak, A. F., Morris, A. D., Matthews, K., Campbell, A., Linksted, P., Haley, C. S., Deary, I. J., Porteous, D. J., MacIntyre, D. J., \& McIntosh, A. M. (2015). Epidemiology And Heritability Of Major Depressive Disorder, Stratified By Age Of Onset, Sex, And Illness Course In Generation Scotland: Scottish Family Health
Study (GS: SFHS). PLoS ONE, 10(11), 1-18.

Fitria, Y., \& Maulidia, R. (2018). Hubungan Antara Dukungan Sosial Keluarga Dengan Depresi Pada Remaja Di Smpn Kota Malang (Relationship Between Social Support With Adolescent Depression in Junior High School at Malang). Prosiding Seminar Nasional Hasil Penelitian Dan Pengabdian Epada Masyarakat III, September, 270-276.

Florensa, Keliat, B. A., \& Wardani, I. Y. (2016). Peningkatan Efikasi Diri Dan Penurunan Depresi. Jurnal Keperawatan Indonesia, 19(3), 169175.

Haryanto, Wahyuningsih, H. D., \& Nandiroh, S. (2015). Sistem Deteksi Gangguan Depresi pada Anak Anak dan Remaja. Jurnal Ilmiah Teknik Industri, 14(2), 142-152.

Hasanah, U., Fitri, N. L., Supardi, S., \& PH, L. (2020). Depression Among College Students Due to the COVID-19 Pandemic. Jurnal Keperawatan Jiwa, 8(4), 421.

Herfinanda, R., \& Kaloeti, V. S. (2021). Family Resilience during the COVID-19 Pandemic: A Systematic Literature Study: Resiliensi Keluarga selama Pandemi COVID-19: Studi Literatur Sistematik. Proceding of Inter-Islamic University Conference on Psychology, 1(1), 1-11.

Huang, C., Wang, Y., Li, X., Ren, L., Zhao, J., Hu, Y., Zhang, L., Fan, G., Xu, J., Gu, X., Cheng, Z., Yu, T., Xia, J., Wei, Y., Wu, W., Xie, X., Yin, W., Li, H., Liu, M., ... Cao, B. (2020). Clinical Features of Patients Infected With 2019 Novel Coronavirus in Wuhan, China. The Lancet, 395(10223), 497-506. 
Hyland, P., Shevlin, M., McBride, O., Murphy, J., Karatzias, T., Bentall, R. P., Martinez, A., \& Vallières, F. (2020). Anxiety And Depression In The Republic Of Ireland During The COVID-19 Pandemic. Acta Psychiatrica Scandinavica, 142(3), 249-256.

Kementerian Kesehatan Republik Indonesia. (2016). Keperawatan Jiwa. Badan Pengembangan dan Pemberdayaan Sumber Daya Manusia.

Liang, L., Ren, H., Cao, R., Hu, Y., Qin, Z., Li, C., \& Mei, S. (2020). The Effect of COVID-19 on Youth Mental Health. Psychiatric Quarterly, 91(3), 841-852.

Maia, B. R., \& Dias, P. C. (2020). Anxiety, Depression And Stress In University Students: The Impact of COVID-19. Estudos de Psicologia (Campinas), $37,1-8$.

Marroquín, B., \& Nolen-Hoeksema, S. (2015). Emotion Regulation And Depressive Symptoms: Close Relationships As Social Context And Influence. Journal of Personality and Social Psychology, 109(5), 836-855.

Marsasina, A., \& Fitrikasari, A. (2016). Gambaran Dan Hubungan Tingkat Depresi Dengan Faktor-Faktor Yang Mempengaruhi Pada Pasien Rawat Jalan Puskesmas (Studi Deskriptif Analitik Di Puskesmas Halmahera Semarang). Jurnal Kedokteran Diponegoro, 5(4), 440450 .

Mazza, C., Ricci, E., Biondi, S., Colasanti, M., Ferracuti, S., Napoli, C., \& Roma, P. (2020). A Nationwide Survey Of Psychological Distress Among Italian People During The Covid-19 Pandemic: Immediate Psychological Responses And
Associated Factors. International Journal of Environmental Research and Public Health, 17(3165), 1-14.

Meridien Research. (2021). The Genetics of Depression. meridienresearch.net.

Murphy, J. M., Bergmann, P., Chiang, C., Sturner, R., Howard, B., Abel, M. R., \& Jellinek, M. (2016). The PSC17: Subscale Scores, Reliability, And Factor Structure In A New National Sample. Pediatrics, 138(3).

National Institute of Mental Health. (2017). Major Depression. www.nimh.nih.gov.

Orth, U., Robins, R. W., Meier, L. L., \& Conger, R. D. (2016). Supplemental Material for Refining the Vulnerability Model of Low SelfEsteem and Depression: Disentangling the Effects of Genuine Self-Esteem and Narcissism. Journal of Personality and Social Psychology, 110(1), 133-149.

Praptikaningtyas, A. A. I., Wahyuni, A. A. S., \& Aryani, L. N. A. (2019). Hubungan Tingkat Depresi pada Remaja dengan Prestasi Akademis Siswa SMA Negeri 4 Denpasar. Jurnal Medika Udayana, 8(7), 1-5.

Purves, K., Coleman, J., Meier, S., Rayner, C., Davis, K., Choi, S. W., Deckert, J., Gaspar, H. A., Hettema, J., Hübel, C., Mattheisen, M., Nicodemus, K., Breen, G., \& Eley, T. (2019). Major Role for Common Genetic Variation in Anxiety Disorders. European Neuropsychopharmacology, 29, S1196.

Putri, K. F., \& Tobing, D. L. (2020). Tingkat Resiliensi dengan Ide Bunuh Diri Pada Remaja. Jurnal Ilmiah Ilmu Keperawatan Indonesia, 10(01), 1-6. 
Rahmayanti, Y. E., \& Rahmawati, T. (2018). Hubungan Dukungan Keluarga Dengan Kejadian Depresi Pada Remaja Awal. Jurnal Asuhan Ibu \& Anak, 3(6), 8.

Safitri, Y., \& Hidayati, N. E. (2013). Hubungan Antara Pola Asuh Orang Tua Dengan Tingkat Depresi Remaja Di Smk 10 November Semarang. Jurnal Keperawatan Jiwa, 1(1), 11-17.

Sahu, P. (2020). Closure of Universities Due to Coronavirus Disease 2019 (COVID-19): Impact on Education and Mental Health of Students and Academic Staff. Cureus, 2019(4).

Santoso, M. B., Siti Asiah, D. H., \& Kirana, C. I. (2018). Bunuh Diri Dan Depresi Dalam Perspektif Pekerjaan Sosial. Prosiding Penelitian Dan Pengabdian Kepada Masyarakat, 4(3), 390.

Schirda, B. L., Nicholas, J. A., \& Prakash, R. S. (2015). Examining The Role Of Trait Mindfulness And Emotion Regulation In Quality Of Life In Multiple Sclerosis. Health Psychology, 34(11), 1107-1115.

Shintia, \& Maharani, W. (2021). Kemampuan Resiliensi Individu dalam Menghadapi Psychological Distress Siswa-Siswi SMA Jakarta di Masa Pandemi Covid-19. Prosiding Konferensi Nasional Universitas Nahdlatul Ulama Indonesia, 1(1), 45-54.

Sholih, Rochani, Khairun, D. Y., \& Alhakim, I. (2017). Meningkatkan Resiliensi Remaja Melalui Bibliocounseling. Jurnal Penelitian Bimbingan Dan Konseling, 2(1).

Sulistyorini, W., \& Sabarisman, M. (2017). Depresi : Suatu Tinjauan Psikologis. Sosio Informa, 3(2), 153-164.
Syahputra, A., Theresa, R. M., \& Bustamam, N. (2018). Hubungan Dukungan Sosial Dengan Tingkat Depresi Pada Mahasiswa Fakultas Kedokteran Universitas Pembangunan Nasional "Veteran" Jakarta Angkatan 2018. Seminar Nasional Riset Kedokteran.

Thapar, A., Collishaw, S., Pine, D. S., \& Thapar, A. K. (2012). Depression in adolescence. The Lancet, 379(9820), 1056-1067.

Uin, S., \& Hidayatullah, S. (2018). Uji Validitas Konstruk Beck Depression Inventory-II (BDI-II). Jurnal Pengukuran Psikologi Dan Pendidikan Indonesia, 4(1).

Vardanyan, A. (2013). Risk Factors And Prevalence Of Adolescent Depression In Yerevan, Armenia (A Cross-Sectional Study) Master of Public Health Integrating Experience Project Professional Publication.

Wahyuningsih, S., \& Mamnu'ah. (2015). Hubungan Faktor Keturunan Dengan Kejadian Gangguan Jiwa Di Desa Banaran Galur Kulor Progo Yogyakarta. Electronic Theses and Disertasi STIKES Aisyiyah Yogyakarta, 1-16.

Williams, J. M. G., Crane, C., Barnhofer, T., Brennan, K., Duggan, D. S., Fennell, M. J. V., Hackmann, A., Krusche, A., Muse, K., Von Rohr, I. R., Shah, D., Crane, R. S., Eames, C., Jones, M., Radford, S., Silverton, S., Sun, Y., WeatherleyJones, E., Whitaker, C. J., ... Russell, I. T. (2014). MindfulnessBased Cognitive Therapy For Preventing Relapse In Recurrent Depression: A Randomized Dismantling Trial. Journal of Consulting and Clinical Psychology, 82(2), 275-286. 
World Health Organization. (2015). Fact

Sheets: Depression. www.who.int. 